breeding could not be utilized in the brewing industry. With the production of baker's yeast, on the other hand, both breeding and heterosis effect have been utilized.

In the science of brewing, Prof. Winge will be specially remembered from his breeding work with barley and hops. The plant-growing part of the work was carried out at 'Nordgården', the experimental farm belonging to the Carlsberg Breweries, where Prof. Winge was the scientific leader during 1938-62. With regard to barley, the variety Carlsberg II, on the market in 1953, attained a wide distribution as a high-yielding and acknowledged malting barley. Its outstanding qualities have left their marks on the European barley-breeding, often being used as crossing material in many European countries.

Winge's work on breeding of hops is especially familiar to specialists, but here it is highly esteemed. We are grateful to Prof. Winge for his review last year in Comptes Rendus des travaux du Laboratoire Carlsberg of his experiences: "Fifty Years of Hop Breeding at the Carlsberg Laboratory and Nordgården".

Prof. Winge received many scientific honours, among those many honorary doctorates, and he was elected a membor of numerous scientific academies all over the world. For several years he was chairman of the group of natural scientists in the Royal Danish Academy of Science and Letters. He was an inspiring teacher, and his researches have been in front ranks both in connexion with yeast and with barley and hop breeding.

\section{Birger Trolle}

\section{Prof. R. McKay}

Robert McKay, who died on May 4 at the age of seventy-five, was emeritus professor of plant pathology in University College, Dublin. Born in County Antrim, he received his early education there. He entered the Royal College of Science for Ireland in 1912, but his studies were interrupted from 1915 until 1919 , during which time he served with the Royal Army Medical Corps in France. In 1920 he became an Associate of the Royal College of Science, and after a short period of service with the Seed Propagation Division of the Department of Agriculture, he joined the Plant Disease Division as Assistant to the late Prof. Paul A. Murphy. Following the death of Prof. Murphy in 1938, McKay became head of the Plant Pathology Department, which had been transferred to University College, Dublin, in 1926. In 1940 he was appointed to the post of lecturer and in the same year was awarded a D.Sc. degree of the National University of Ireland. He was appointed professor of plant pathology in 1945 .

Prof. McKay's earliest work, in collaboration with Prof. Murphy, was concerned mainly with investigations on potato virus diseases. The technique worked out by these investigators of testing nucleus stocks of potatoes in the glasshouse and propagating such stocks under conditions of good isolation and rigid inspection has been largely responsible for the high repute in which Irish seed potatoes are held.

Onion mildew was probably the first of the fungal diseases worked on by Prof. McKay. With Prof. Murphy, he demonstrated the presence of hibernating mycelium in bulbs from diseased plants and that such mycelium could be killed by heat treatment. This is one of the first references to control of a fungus disease by heat treatment. Prof. McKay was the first to observe the germination of the oospores of the onion mildew fungus, and he showed that such spores could remain viable in the soil for up to twenty years. His work on diseases of cereals, particularly on Septoria leaf spot of barley, Helminthosporium leaf spot of oats and diseases of wheat caused by Gibberella has added much to our knowledge concerning these maladies. During the Second World War, flax growing was an important industry in Iroland, and Prof. McKay made a study of the diseases cecurring on that crop. With his co-workers, he was the first to demonstrate clearly that the fungus causing the pasmo disease of flax was seed-borne. He carried out spraying trials on the control of apple scab over many years and he pointed out the importance of bud scale infection as a source of the apple scab fungus under Irish conditions. $\mathrm{He}$ studied beet diseases, and it was mainly due to his advice to the Irish Sugar Company that the practice of growing stecklings and sugar-beet crops in isolation was adopted many years ago. This practice has resulted in considerable reduction in such diseases as virus yellows and downy mildew in these crops. Among other diseases which he investigated were blight and scab of potatoes.

As adviser in plant pathology to the Department of Agriculture, he came in contact with most of the diseases occurring on commercial crops in Ireland. The knowledge thus gained ho committed to writing in a series of monographs on diseases of individual crops. These monographs, so well and so profusely illustrated, are of immense value to growers, advisers and students of plant pathology.

His monographs on diseases were subsidized by the Irish Sugar Co. (sugar beet diseases), the Irish Potato Marketing Co. (potato diseasss), Messrs. Guinness (cereal diseases), and the Flax Development Board (flax diseases). $\mathrm{He}$ was honoured by the Royal Horticultural Society of Ireland by the award of the Medal of Honour in 1948 and by the Royal Dublin Society by the award of the Boyle Medal in 1957.

Prof. McKay's work covered a wide field of research, but it was always carried out with thoroughness and perseverance. Whether fundamental or applied, all of it is sound and reliable.

As a teacher, Prof. McKay is remembered with affection and respect by hundreds of graduates in agriculture. As a lecturer he was painstaking in keeping up to date with his subject and in delivery he was clear and lucid. His lectures were often interspersed with witticisms, for he had a lively sense of humour. Under the auspices of the Royal Dublin Society he lectured on plant diseases to growers in almost every county in Ireland. His practical approach to the subject, and his awareness of their needs, earned him the appreciation of growers throughout the country.

J. B. LoUGHNANE

\section{Miss E.JH. Ekins, O.B.E.}

Miss E. H. Ekrns died at Hitchin, Hertfordshire, on June 4. She was eighty-four.

Emily Helen Ekins, daughter of A. E. Ekins, public health analyst for Hertfordshire, was educated at St. Albans High School, the University of Birmingham and Studley College, Warwickshire. She joined the staff of Studley College as a lecturer in horticulture in 1911, became acting warden in 1922 and principal in 1924, which position she held until August 1946. She was awarded the O.B.E. in recognition of her sorvices to agricultural education in 1934 .

Miss Ekins will long be remembered as one of the pioneers of agricultural and horticultural education for women. During the twenty-two years she held office as principal of Studley College she put her whole-hearted energy into consolidation of the administrative and educational sides. Building dovelopments began in 1925; two appeals were launched, one to purchase the freehold of the property from the Warwick Estate and the second for the building of science laboratories and study bedrooms, and despite difficulties and frustrations, all-round progress in the history of the College was evident, brought about by her integrity and single-mindedness. She will also be remembered by hundreds of students who recognize and appreciate the vast amount of service which she so generously gave; she was the chief link in binding together each generation of students throughout her long association with the College, and many of them will remember with gratitude the help and encouragement sho gave during their training and early days of their carcer. 